\title{
Modeling and Molecular Docking Studies on Alangium salvifolium (Alanginaceae) as a Target for Anti-oxidant Enzyme
}

\author{
Mohammad Nadeem Khan ${ }^{1^{*}}$ \\ ${ }^{1}$ School of Studies in Biotechnology, Bastar University, Jagdalpur, Chattisgarh-494001, India.
}

Author's contribution

The sole author designed, analysed, interpreted and prepared the manuscript.

Article Information

DOI: 10.9734/ARRB/2019/v33i430129

Editor(s):

(1) Dr. J. David Puett, Professor, Department of Biochemistry and Molecular Biology, University of Georgia, Athens, USA.

(2) Dr. George Perry, Dean and Professor of Biology, University of Texas at San Antonio, USA.

Reviewers:

(1) Idakwoji Precious Adejoh, Kogi State University, Nigeria.

(2) Pankaj G. Jain, R. C. Patel Institute of Pharmaceutical Education and Research, India.

Complete Peer review History: https://sdiarticle4.com/review-history/45646

Original Research Article

Received 12 November 2018

Accepted 16 January 2019

Published 01 November 2019

\begin{abstract}
Objectives: The present studies pursue at retrieve and draws the active phytocompounds structure of Alangium salvifolium and assessing its simulation anti-oxidant enzyme activities.

Methods: Retrieve/draws of the compounds were carried out using chem.-sketch software. The 3-D structures of the Phytocompounds were visualized based upon the UV, NMR spectral data along with their energy simulation studies. The antioxidant and enzyme simulation activity were evaluated in-silico using the ACD labs,PyRx, RASMOL,PYMOL,Aragslab and Discovery 3.1 studio.

Key Findings: Phytochemicals structure drawing of $A$. salvifolium resulted in the structured and recognition of four phytochemicals. The plant phytochemicals showed significant anti-oxidant enzymes activity enhancer and ROS eliminator through binding to its metal domain receptor.

Conclusion: Phytochemicals were drawing from $A$. salvifolium. To the best of our knowledge, among these phytochemicals, were studied anti-oxidant enzymes metals binding domain to increase the ROS scavenging activity for the foremost time from mimic with molecular docking. Moreover, study of phytochemicals simulation was for the first time from this plant. The plant revealed auspicious increase the antioxidant activities virtual screening. This gives thinking to some of its pharmacological properties and suggests additional antioxidant effects, for as a scavenger as well as anti-oxidant enzyme stimulator, which have not been reported yet.
\end{abstract}


Keywords: Alangium salvifolium; phytochemicals; molecular docking study; ROS elimination activity.

\section{INTRODUCTION}

Plants have been nearly for the therapeutic baseline of various diseases optimistically from the decades by knowledge of Ayurveda in our country. New drug discovery and development Plants are basic and most abundant source of new discoveries for the new drug escort towards various healthcare issues Organic chemical compounds (Phytochemical) found in plants that are not required for normal functioning of the body, but have a beneficial effect on health or play an active role in relieve of diseases [1]. The effectiveness plant secondary metabolites in the treatment of various diseases may lie in their antioxidant effects [2]. Oxygen is an element compulsory for life; living systems have evolved to survive in the presence of molecular oxygen and most biological systems. Oxidative properties of oxygen play a vital role in diverse biological happening. Oxygen has double-edged properties, being essential for life; it can also aggravate the damage within the cell by oxidative facts [3].

Alangium salvifolium wang member of the family of Alanginaceae. Ankola and Alangi are its common name in India, and Stone Mango in English. It is a small broad-leaved thorny tree or shrub [4] which is dispersed in tropical and subtropical region such as Bangladesh, India, China Phillipines, Africa, Srilanka and Indochina [5]. A range of ailments including diabetes, jaundice, gastric disorders, protozoal diseases, rheumatic pain, burning sensation, haemorrhages, lung cancer, poisonings, leprosy and many inflammatory patches have been treated by using various parts of the plant [6]. Many bioactive phytochemicals such as assorted flavanoids, phenolic compounds, irridoid glycosides and oxyoglucosides have been isolated by phytochemical screening of it [7]. Previous literature citated that plants indicate the presence of coumarins, triterpenoids and some potent alkaloids in it [8]. Antioxidants enzymes play a very important role in lessening problems related to oxidative stress. The antioxidant enzymes of phytocompounds isolated from appraised medicinal plants Costunolide (20 $\mathrm{mg} / \mathrm{kg}$ ) or Eremanthin $(20 \mathrm{mg} / \mathrm{kg}$ ) for 60 days caused a significant increase in enzymatic activity of SOD, CAT and GPx, when compared with untreated $[9,10]$ Moreover, maximum antioxidant probable, including $\mathrm{DPPH}$ radical scavenging $\left(\mathrm{IC}_{50}: 11.26 \pm 1.29 \mu \mathrm{g} / \mathrm{ml}\right)$, FRAP $\left(E_{50}: 26.64 \pm 2.17 \mu \mathrm{g} / \mathrm{ml}\right)$ and TAC $(639.55 \pm 10.51 \mathrm{mg} / \mathrm{g}$ ascorbic acid) was found in the CASR. Donepezil, to prime of our knowledge, the receptor-level mechanism behind this process is no where mentioned. Present study was aimed at the analysis of receptor-level binding affinity of secondary metabolites of Alangium salvifolium with SOD, CAT and GPx through molecular docking.

\section{METHODS}

\subsection{Design of Small Molecules (Ligand)}

To study inhibition of antioxidant enzyme with sketch small molecules (called as ligand), Alangium salvifolium based known phytochemicals are selected as listed in Table 1.

\subsection{Ligand Preparation}

The structures of polycyclic aromatic organic compounds based plant-derived compounds are represented in-silico using Chem-Sketch software [11]. Initially 2-D structures were designed. The 2-D compounds converted to 3D employing Molecular Mechanics (MM2) method with the help of Chem-Sketch software [12]. The designed molecules are scrutinized for its conformation by ascertaining achievement of global minima. The list of compounds designed along with molecular formula is listed in Table 1, Fig. 2.

\subsection{Receptor Enzyme}

Electronic structure of AEs is picked as a target protein having PDB reference $2 \mathrm{BHH}$. The protein file obtained from online data base having SOD, CAT, GPx an antioxidant enzymes. The selected enzyme structure was produced by online homology modeling tool in such a way that it has no ambiguities in the form of missing atoms or amino acids. All the heteroatoms (i.e. nonreceptor atoms such as water, ions, etc.) were detached followed by assigning Kollmann charges. The Solvation variables were added to the final macromolecule structure using the Addsol utility of Auto-Dock [13]. The place of natural inhibitor in enzyme is served as active site ofselected enzyme and used as it is without any further processing. 


\subsection{Molecular Docking}

Autodock 4.0 [14] is used for docking operations. Initially protein grid was designed using grid design tool of Autodock. Dockings were achieving used both genetic (GA) and nongenetic (Non-GA) algorithm techniques. The genetic algorithm (GA) is the newly adopted conformational search techniques and searches the best possible conformations of ligand inside the active site of enzyme. For each conformational position, it also reports the possible binding energy in the form of $\Delta G$ in kcal.mol-1. The selected parameters and settings, which were used for docking, are listed in Table 2. The docking algorithm makes use of force field equations and parameters to calculate the binding energy between ligand and enzyme [15-17]. The binding free energy is the total of van der Waals interactions, $\mathrm{H}$-bond interactions, electrostatic interactions and the internal static energy of the ligand as shown in Equation 1 [18-20].
$\Delta \mathrm{Gbind}=\Delta \mathrm{Gvdw}+\Delta \mathrm{G}$ hydrophobic $+\Delta \mathrm{GH}-$

bond $+\Delta G H$-bond (chg) $+\Delta$ Gdeformation $+\Delta G$

The obtained results of binding energy for NonGA and GA Dockings for each set of experiments are listed in Table-3. The negative values of docking energies favour the interaction among ligand and enzyme. Though there are chances of non-favourable interactions, the non-favourable results are marked as '*'.

\subsection{Receptor Ligands Interaction Study}

Docking was ready with the PyRx software (pyrax-www.pyraxviana.com/), in which the result is being obtained on the basis of pose energy. Docking interaction analysis and visualization attempt to place 'Ligand into Binding Sites'. The interaction 2D binding affinity cavity and binding pattern were expressed. The atoms that construct bond between Ligand like inhibitor, and the Binding Site on the protein where the inhibitors bind that Structure were drawn in Discovery studio 3.1 version.

Table 1. Protein (Receptor) general information

\begin{tabular}{llllll}
\hline S.no & Protein name & PDB ID & Enzyme code & No of chain & Total amino acids \\
\hline 1 & SOD & 1PM9 & EC 1.15 .1 .1 & 2 & 420 \\
2 & CAT & 1QQW & EC 1.11 .1 .6 & 4 & 2108 \\
3 & GPx & 1BY & EC 1.11.1.7 & 1 & 215 \\
\hline
\end{tabular}

Table 2. General Properties of phytochemicals obtained from Alangium salvifolium

\begin{tabular}{|c|c|c|c|c|c|}
\hline $\begin{array}{l}\text { S. } \\
\text { no. }\end{array}$ & Properties & Alangium 1 & Alangium 2 & Alangium 3 & Alangium 4 \\
\hline$\overline{1}$ & $\begin{array}{l}\text { Name of } \\
\text { chemicals }\end{array}$ & $\begin{array}{l}\text { 4(benzoyloxy)methyl } \\
\text {-2hydroxyphenoxy } \\
\text { tetrahydorxy } \\
\text { hexoxone } 1,2,3,4,5 \text {, } \\
\text { pentaium }\end{array}$ & & $\begin{array}{l}\text { Tetahydroxy(2hydro } \\
\text { xy phenoxy)hexone } \\
1,2,3,4,5 \text { pentaium }\end{array}$ & $\begin{array}{l}\text { Tetahydroxy(2hydro } \\
\text { xy phenoxy)hexone } \\
1,2,3,4,5 \text { pentaium }\end{array}$ \\
\hline 2 & $\begin{array}{l}\text { Molecular } \\
\text { formula }\end{array}$ & $\mathrm{C}_{14} \mathrm{H}_{15} \mathrm{O}_{14}$ & $\mathrm{C}_{17} \mathrm{H}_{23} \mathrm{O}_{12}$ & $\mathrm{C}_{6} \mathrm{H}_{9} \mathrm{O}_{12}$ & $\mathrm{C}_{16} \mathrm{H}_{12} \mathrm{O}_{4}$ \\
\hline 3 & $\begin{array}{l}\text { molecular } \\
\text { weight }\end{array}$ & 407.26 & 419.36 & 273.13 & 268.26 \\
\hline 4 & Composition & & & & \\
\hline 5 & $\begin{array}{l}\text { Molar } \\
\text { refractivity }\end{array}$ & 81.88 & 94.46 & 46.12 & 76.43 \\
\hline
\end{tabular}

Table 3. Ligand lead energy simulation and pharmacophore specification (Argus lab) results

\begin{tabular}{llllll}
\hline S.No & Specification & Alangium 1 & Alangium 2 & Alangium 3 & Alangium 4 \\
\hline 1 & SCF energy & -231.767296889 & -300.7076472584 & 47.3947768704 & 213.3165388741 \\
2 & Geometry & 231.819691035 & -300.771772957 & 47.521422858 & $213.325870339 s s s$ \\
\hline
\end{tabular}



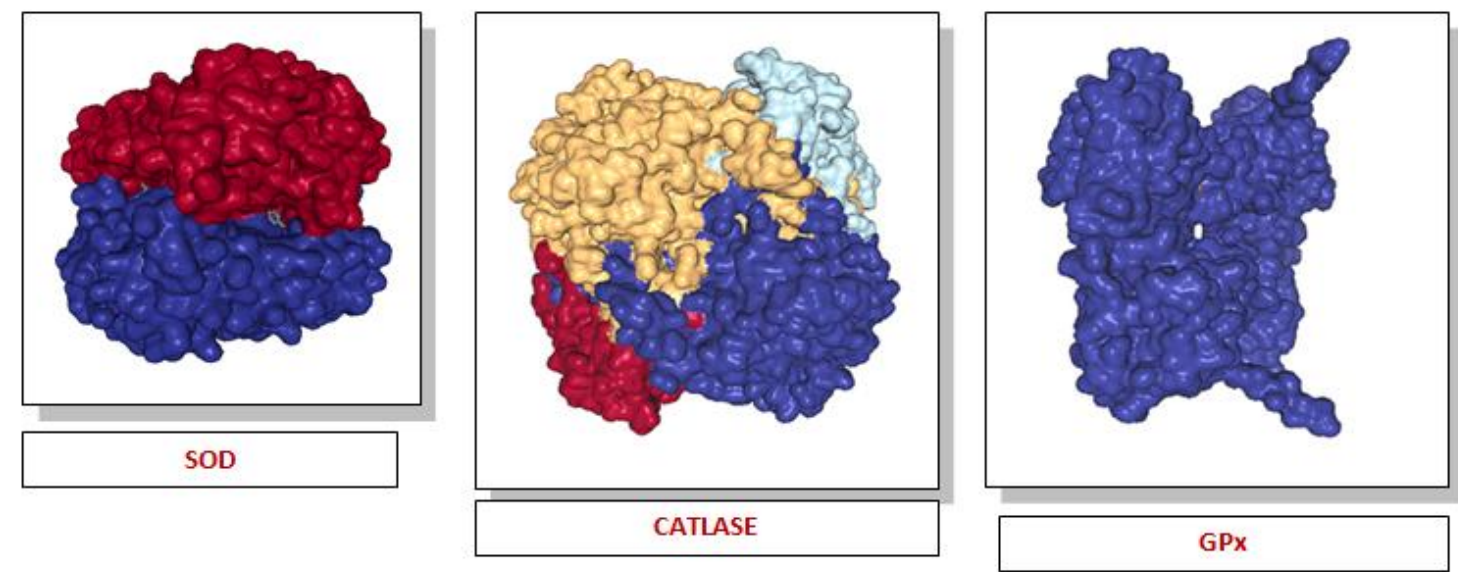

Fig. 1. Antioxidant enzymes model x-ray crystalogrphy structure

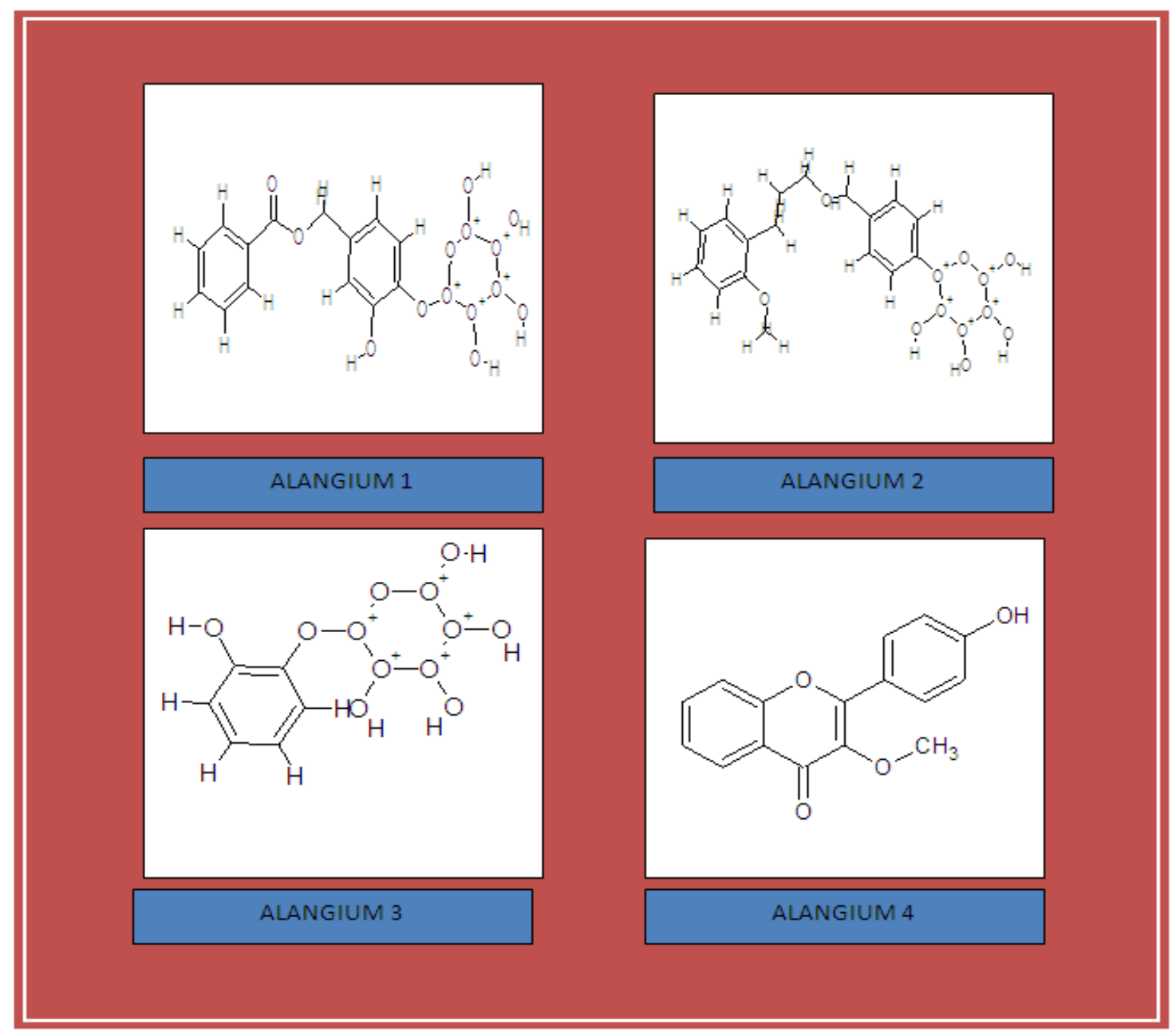

Fig. 2. Chemical structures of Alangium salvifolium Phytochemicals obtained from ChemSketch (2D) 
Table 4. Mean values of docking energies $(\mathrm{kcal} / \mathrm{mol})$ and standard deviation for each skeletal type of Alangium salvifolium phytochemicals as liagands with anti-oxidant enzymes enzyme targets

\begin{tabular}{lllllll}
\hline Target & Ligands & $\begin{array}{l}\text { Dimension } \\
\text { Centre(x=25Ay=25z=25) }\end{array}$ & $\begin{array}{l}\text { No of } \\
\text { pose }\end{array}$ & $\begin{array}{l}\text { RSD } \\
\text { \%lower }\end{array}$ & $\begin{array}{l}\text { RSD } \\
\text { \%upper }\end{array}$ & $\begin{array}{l}\text { Mean } \\
\text { binding }\end{array}$ \\
\hline SOD & Alangium & $\begin{array}{l}\mathrm{X}=16.0161, Y=70.1678, \\
Z=15.4010\end{array}$ & 9 & $114.74 \%$ & $57.7 \%$ & -7.6 \\
& 1 & & 9 & $52.72 \%$ & $57.72 \%$ & -7.0 \\
& 2 & & 9 & $103.74 \%$ & $89.09 \%$ & -6.3 \\
& 3 & & 9 & $42.62 \%$ & $39.74 \%$ & -7.4 \\
\hline CAT & 1 & $\mathrm{X}=48.844 \mathrm{y}=101.718$ & 9 & $61.17 \%$ & $54.60 \%$ & -8.9 \\
& 2 & $\mathrm{Z}=38.2861$ & 9 & $49.96 \%$ & $51.85 \%$ & -8.3 \\
& 3 & & 9 & $72.23 \%$ & $67.91 \%$ & -6.7 \\
& 4 & & 9 & $47.92 \%$ & $45.56 \%$ & -8.1 \\
\hline GPX & 1 & $\mathrm{X}=-12.041 \mathrm{y}=22.8816$ & 6 & $75.32 \%$ & $78.04 \%$ & -7.1 \\
& 2 & $\mathrm{Z}=9.2389$ & 4 & $79.61 \%$ & $68.17 \%$ & -4.7 \\
& 3 & & 9 & $151.01 \%$ & $122.16 \%$ & -5.5 \\
& $\% 4$ & & 6 & $56.07 \%$ & 61.34 & -4.4 \\
\hline
\end{tabular}

\section{RESULTS}

The SOD, CAT and GPx x-ray crystallography structure proteins were redeemed and examine and it was docked to phytochemical compounds from A. salvifolium. The results are presented as follow:

\subsection{Retrieving Three Dimensional Structures of Anti-oxidant Enzymes}

The structure of antioxidant enzymes (AE) SOD, CAT, and GPx with PDB Id: 1PM9, 1QQW, 1BY were as taken for further analysis. This structure was scaned to know details of the AE molecule. The secondary structure information about AEs proteins have been retrieved from PDB sum database. The topology of the different secondary structures of AEs and the amino acid residues in which each helices and sheets are established. The three-dimensiona structures of $A E$ are composed of similar $\alpha / \beta$ TIM barrels. The symmetry of the TIM barrel is disrupted by the presence of two short anti-parallel $\beta$-strands at the $\mathrm{N}$-terminus connected by a tight turn closing the bottom of the barrel [21]. The PDB file was downloaded and viewed in Ras $\mathrm{Mol}$ and their various models are given in Table 1 Fig. 1a, b,c.

\subsection{Binding Site Prediction - Q-Site Finder}

The protein structure of $A E$ was given as load to Q-Site Finder tool and binding site of the protein was prophesy. Ten best 'binding sites' were predicted. The amino acids and the atoms involved in the site were listed.

\subsection{Drawing Three Dimensional Structures of Inhibitors}

\subsubsection{Chemsketch (ACD labs)}

The chemical structure of the patronaging $A$. salvifolium APIs collected from literatures were drawn in ChemSketch and visualise into $2 \mathrm{D}$ and 3D dimensional structures and its general properties were summarized in Table 2 Fig. 2.

\subsection{Making legends Pharmacophore by Using of ArgusLab}

Ligands energy extent and its simulation properties were assess by using of Argus Lab software. Various energy level calculation and visualization was summarized in Table -3 and Fig. 3.

\subsection{Docking (Autodock-Viana)}

Using PyRx (Autodock 4-0) version, the receptor, AEs.pdb file and the ligand pdb file were taken and the protein side chain molecules were detached with the help of various tool controls for their perfect visualization. Hetero atoms were removed and the molecule was used for docking. The binding site molecules were kept as separate PDB file and that was used for the analysis. Then, the protein file and the ligand $\mathrm{pdb}$ file were loaded and docking studies were performed. The best docked conformation with its binding energy was found and details are given Table 3. While executing docking the protein and ligand appeared in a grid as shown below and the various binding configurations are 
analyzed and finally the list of number poses are given as output and saved as .SDF files. Hydrogen bonds were appended and energy was minimized using CHARMm force field. Further, docking studies also carried out using Discovery studio 3.1 version.

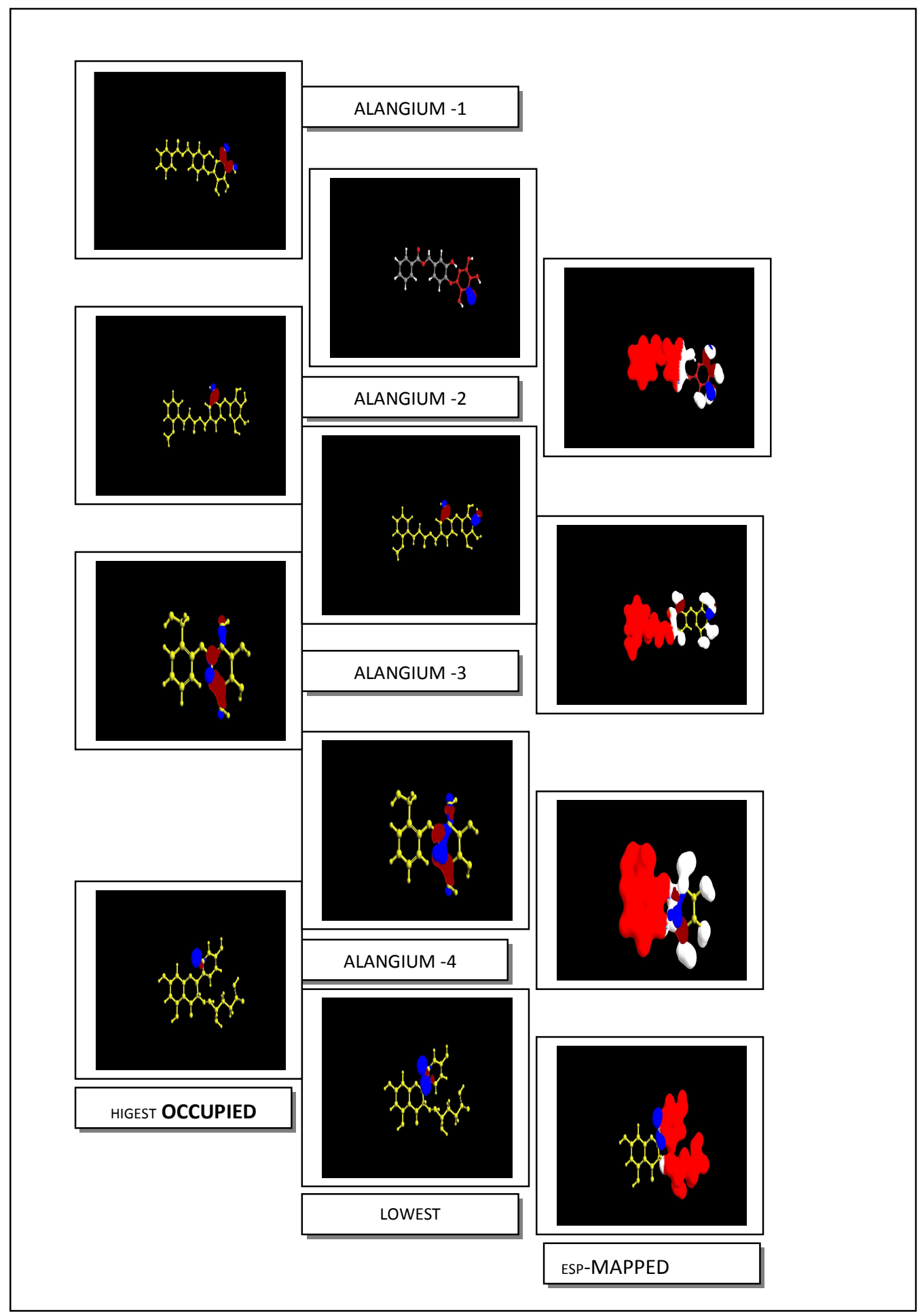

Fig. 3. Ligand leads acquired energy simulation images produced by Argus lab software 


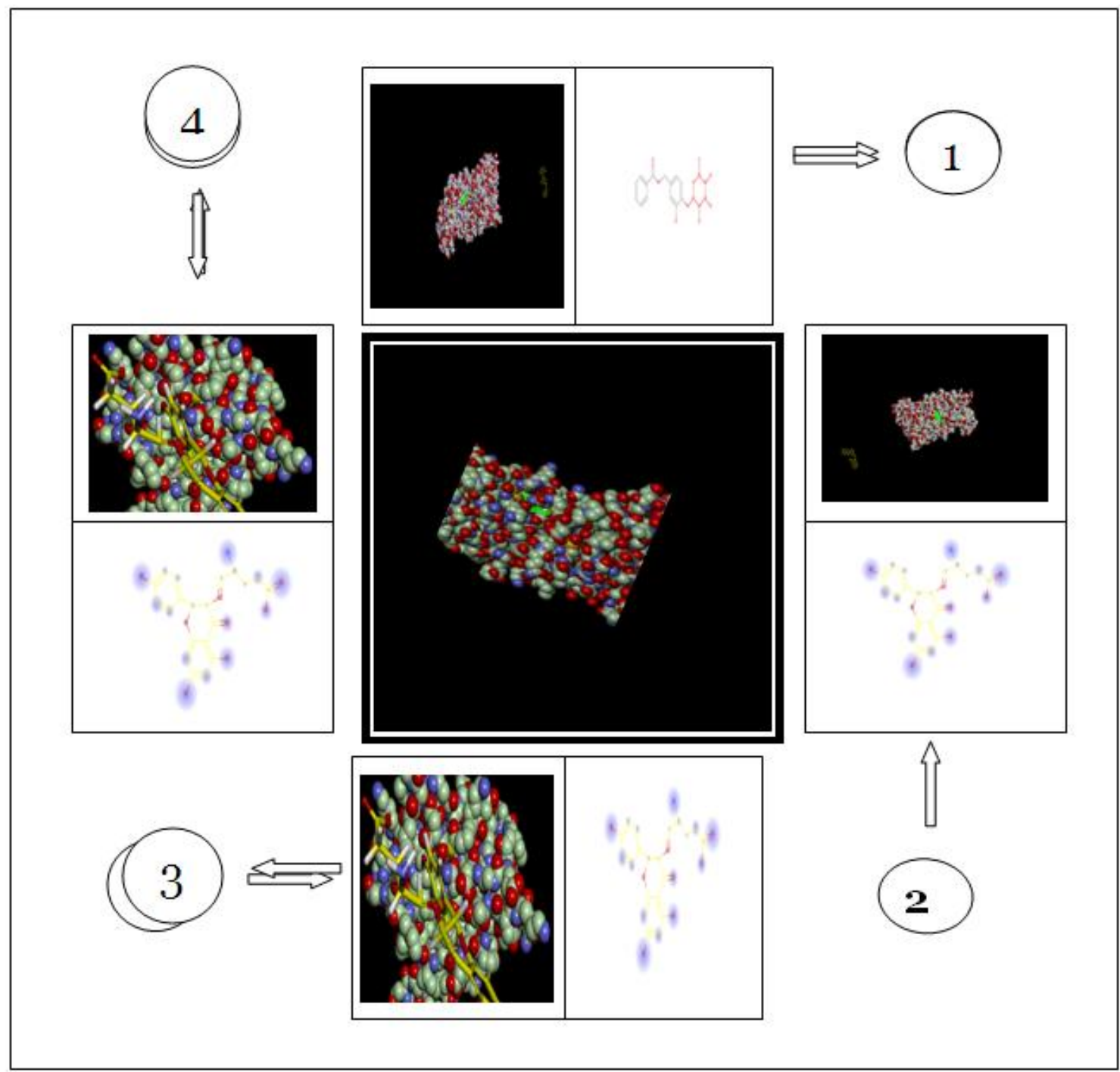

Fig. 4. The binding analysis and the ligand interaction between SOD (1PM9) and phytocompound of $A$. salvifolium

The $A$. salvifolium phytochemicals effectively docked in to the binding site of AEs protein indicating that they are efficient drug compounds. All these binding ligands viz., 4(benzoyloxy) methyl-2hydroxyphenoxy tetrahydorxy hexoxone 1,2,3,4,5, pentaium Tetahydroxy(2hydroxy phenoxy)hexone 1,2,3,4,5 pentaium, Tetahydroxy(2hydroxy phenoxy)hexone 1,2,3,4,5 pentaium showed efficient docking as indicated by binding energy and all are efficient inhibitors.

\subsection{Interaction Analysis}

Interaction between receptor (Protein) and ligands (Phytocompounds) on the basis of ligands pharamcophore belonged and receptor protein binding cavity. Inside the cavity ligands was oriented in different pose and making a weak hydrogen or hydrophobic bond formation. Receptor protein amino acid and ligands possible potential arms interact each other and make a binding affinity the interaction of protein and Phytocompounds of Alangium salvifolium were curtail and depicted in 2D and 3D structure in Figs. 4,5,6.

\section{DISCUSSION}

Antioxidant enzymes have ability to stabilizing, or deactivating free radicals before they attack 
cellular components. They play key role by reducing the energy of the free radicals or by giving up some of their electrons for its use, thereby causing it to become stable. In addition, they may also interrupt with the oxidizing chain reaction to minimize the damage caused by free radicals. For the past decade, countless studies have been devoted to the beneficial effects of antioxidant enzymes [22]. The SOD enzyme demolishs the superoxide radical; however, as a result of that it creates hydrogen peroxide, which also has high toxic properties [23]. It has been reported as one of the most important antioxidant defense enzyme that scavenge superoxide anion by converting to hydrogen peroxide thus diminish the toxic effect caused by this radical [24]. Catalase is a tetrahedrical protein, constituted by four heme groups which catalyze the dismutation of hydrogen peroxide in water and oxygen [25] Phenol oxidases are copper proteins catalyse the aerobic oxidation of certain phenolic compounds to quinones. Polyphenol oxidase is one of the major enzymes that have a role in the biosynthesis of lignin and defense against water stress by scavenges $\mathrm{H}_{2} \mathrm{O}_{2}$ in chloroplasts [26]. Glutathione S-transferases (GSTs), a family of cytosolic multifunctional enzymes. It catalyzes the conjugation of glutathione with a variety of reactive electrophilic compounds, thereby neutralizing their active electrophilic sites and subsequently making the parent compound more water soluble. Glutathione peroxidases are substantially more efficient on a molar basis than other enzymes [27]. Glutathione peroxidase acts as a radical scavenger, membrane stabilizer and precursor of heavy metal binding peptides.

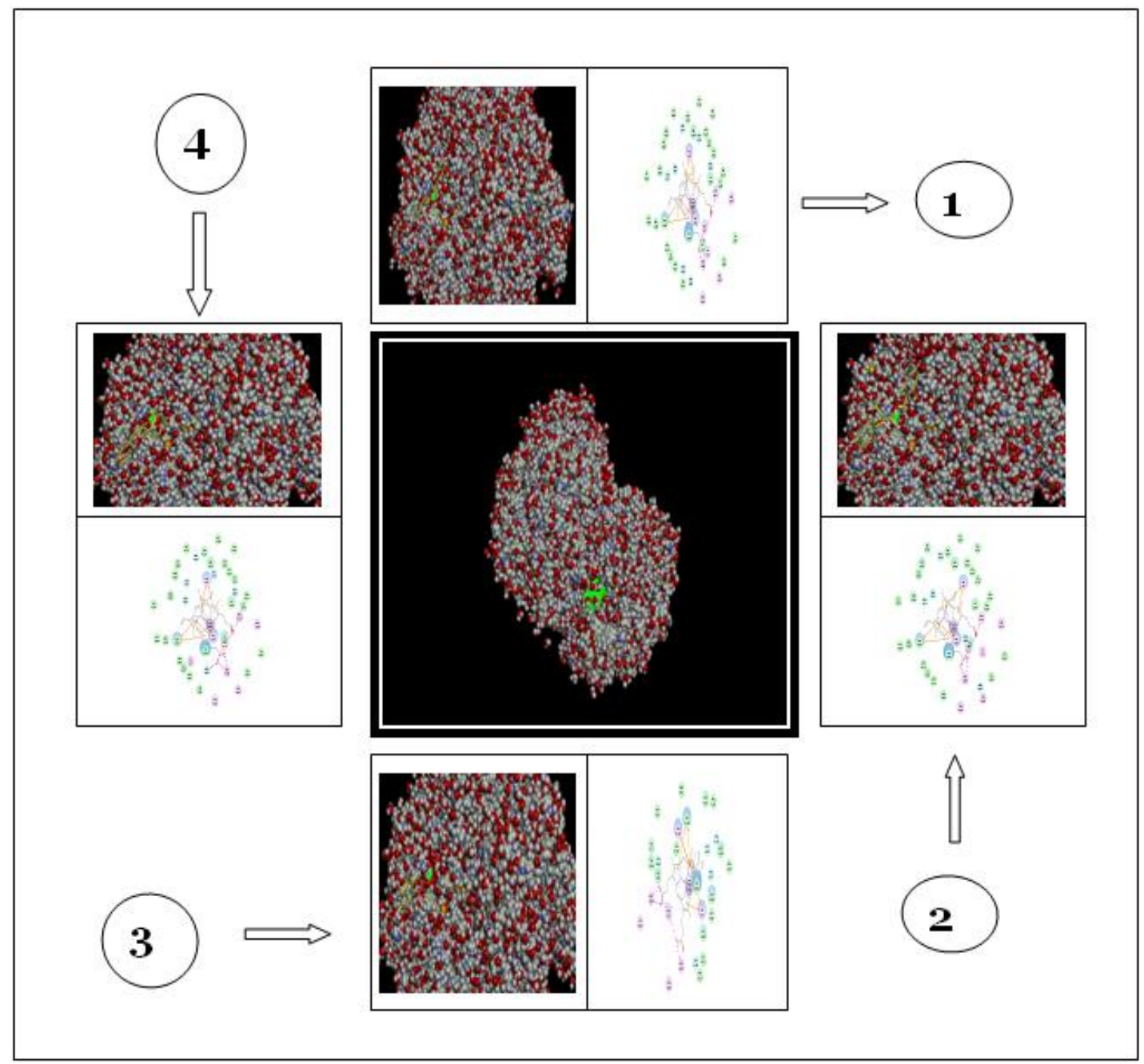

Fig. 5. The binding analysis and the ligand interaction between Catalase (1QQW) and phytocompound of $A$. salvifolium 


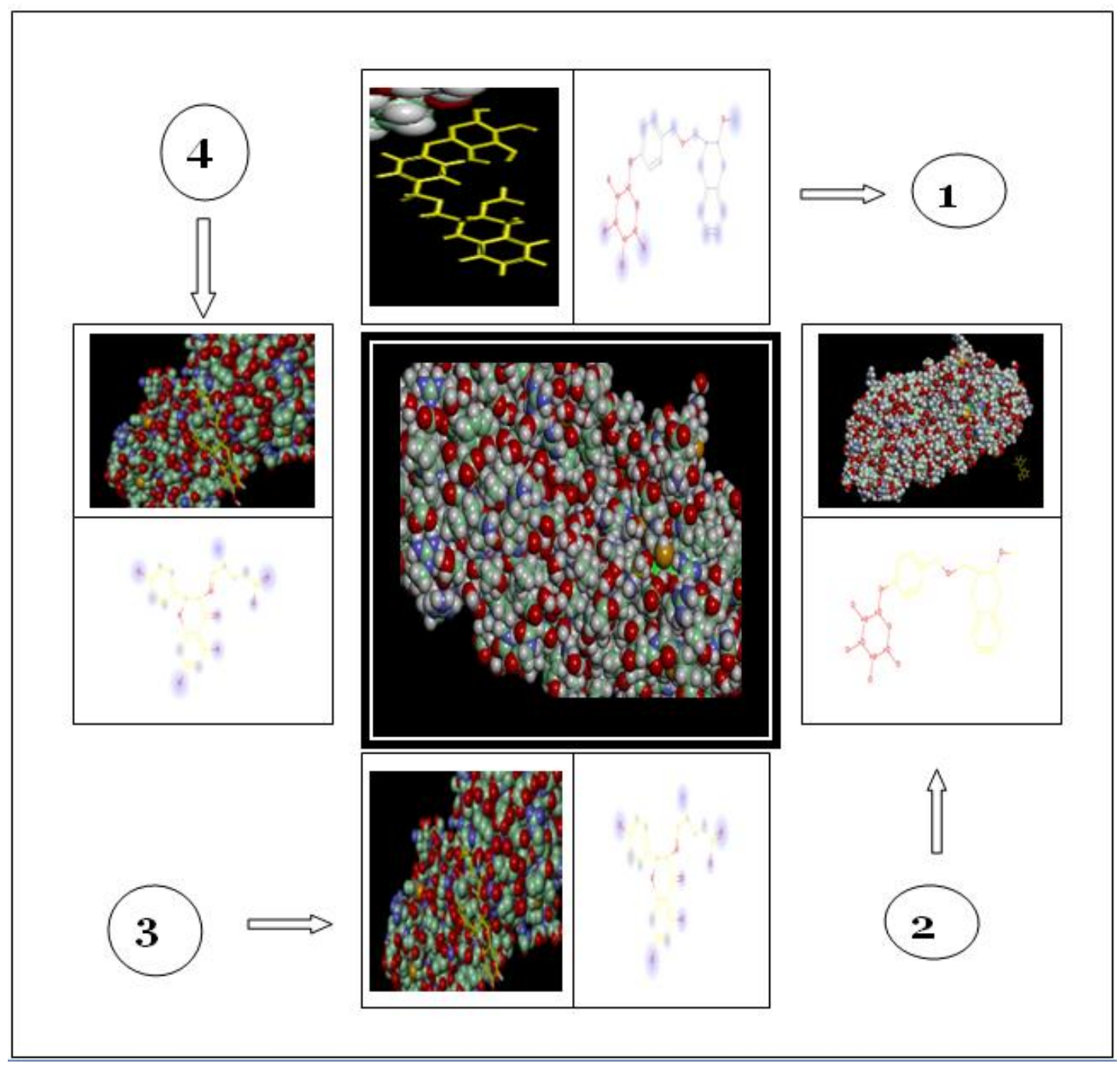

Fig. 6. The binding analysis and the ligand interaction between GPx (1BY) and phytocompound of $A$. salvifolium

NOS enzyme crystal structure complexed with inhibitor was taken for our study to discover novel hit molecule for antioxidant drug discovery. The reference ligand was docked into the active site of the enzyme. The amino group of reference ligand was found to interact with positively charged amino acid Glu592 and non-polar amino acid Trp587. The phyto-compounds selected for A. salvifolium in this study was made to dock into the active site pocket of the antioxidant enzymes(SOD) and found that the compound code Alangium-1(4(benzoyloxy)methyl2hydroxyphenoxy tetrahydorxy hexoxone $1,2,3,4,5$, pentaium) was found to be best docking score as an binding affinity $(-\mathrm{kcal} / \mathrm{mol}$. The closer analysis of the compound was analyzed and found that the compound was found to interact with the amino acid Ser457, Thr231 and the benzyl group is stacked with the non-polar amino acid Trp409. The 3-dimensional view of this molecule reveals that the compound was well fitted into the active site cavity which made this molecule more effective binding than the reference ligand. Furthermore, the nitro group and methoxyphenyl group was well surrounded by the non-polar amino acids. The binding analysis and the ligand interaction 2D, 3D diagram was depicted in the Fig. 4.

The target receptor of catalase(CAT) showed the excellent docking score to liagand (Alangium-1) further discuss about this compound binding analysis and interactions, the amino acid Ser257,Thr245 and Ala 235 donates 
one hydrogen atom to the compound and the chloro benzilic group was found to be firm interact with two stacking interaction with nonpolar amino acids Trp409 and Phe584. Furthermore, the compound is fully surrounded by the non-polar amino acids such as Val167, Ala266, and Ile324 which made this compound possess better docking score than others. The binding analysis and the docking score of the compound were depicted in Fig. 5.

The GPx antioxidant enzyme showed the good docking score against the Alangium-1. Further, the structure-activity relationship of this compound reveals that the metal binding domain group is showing a stacking interaction with Trp209. Due to the presence of bulky heme group present site on the both the side of this compound, the compound tends to powerful its activity on binding with the enzyme [12]. The binding analysis and the ligand interaction of the compound were depicted in Fig. 6.which made this compound more active than without these phytocompounds because the Alangium phytocompounds firmly bind with metal binding domain which give superior stability to bind the metal group for anti-xoidents enzymes. Therefore increase its scavenging activity for reactive oxygen species (ROS) and reduce the oxidative stress. Inside the cell [13]. The binding analysis and the ligand interaction of the GPx and Alangium-1 phytocompound were depicted in Fig. 6. The antioxidant enzymes studied in this research, the 3-dimensional representation of this interaction reveals that the interaction between receptor and ligands is closed from the metal binding domain site.

\section{CONCLUSION}

All the four components have more or less similar docking energies and so all the four compounds can be used for good binding affinity in different pose site AEs activity. It might be expected that the active components isolated from $A$. salvifolium phytochemicals would have some pharmacological actions to promote the oxidative radical scavenging activity SOD, CAT and GPx enzymes. Further this may be confirmed by drug trials in In-vitro and In-vivo models to find out the optimum dose and its efficiency in binding actively AEs.

\section{COMPETING INTERESTS}

Author has declared that no competing interests exist.

\section{REFERENCES}

1. Akinmoladun AC, Ibubun EO, Afor E, Obuetor EM, Farombi EO. Phytochemical constituent and antioxidant activity of extract from the leaves of Ocimum gratissimum. Sci Res Essay. 2007;2:163-6.

2. Shinde V, Dhalwal K, Paradkar AR, Mahadik KR, Kadam SS. Evaluation of in vitro antioxidant activity of human placental extract. Pharmacol Online. 2006;3:172-9.

3. Uthiraselvam M, Asmathu FS, Peer $\mathrm{MH}$, Babu SM, Kavitha G. Pharmacognostical studies on the medicinal plant - Alangium salvifolium (Linn. F) Wang. (Alangiaceae). Asian J. Plant Sci. Res. 2012;2(6):670674.

4. Ronok Z, Laizuman N, Luthfun NM. Antinociceptive and anti-inflammatory activities of flower (Alangium salvifolium) extracts. Pak. J. Bio. Sci. 2013;16(19): 1040-1045.

5. Meera $R$, Shabina $S$, Devi $P$, Venkataraman S, Parameswari PT, Nagarajan K, Aruna A. Anti-hyperglycemic effect of aqueous and ethanolic extracts of leaf and stem bark of Alangium salvifolium (L.F.) Wang in alloxan induced diabetic rats. Inter. J. Phar. Res. Allied Sci. 2013; 2(4):28-32.

6. Gopinath SM. Broad spectrum antimicrobial activities and phytochemical analysis of Alangium salviifolium flower extract. Global J. Res. Med. Plants Indigen. Med. 2013;2(3):135-141.

7. Savithramma N, Ling RM, Ankanna S. Preliminary phytochemical screening of some important medicinal plants. Inter. J Ayur. Herbal Med. 2012;2(1):139-145.

8. Worthington Enzyme Manual. Worthington Biochemical Corporation; 2009.

9. Frank L. Prolonged survival after paraquat: Role of the lung antioxidant enzyme systems. Biochem Pharmacol. 1981;30: 2319-2324.

10. Bagley A, Krall J, Lynch R. Superoxide mediates the toxicity of paraquat for Chinese hamster ovary cells. Proc Natl Acad Sci USA. 1986;83:3189-3193.

11. Bus JS, Gibson JE. Paraquat: Model for oxidant-initiated toxicity. Environ Health Perspect. 1984;55:37-46.

12. Stevens TM, Boswell GA, Adler R, Ackerman NR, Kerr JS. Induction of antioxidant enzyme activities by a phenylurea derivative, EDU. Toxicol Appl Pharmacol. 1988;96:33-42 . 
13. Saito K. Effects of paraquat on macromolecule synthesis in cultured pneumocytes. Tohoku J Exp Med. 1986;148:303312.

14. Kelner M, Bagnell R. Generation of endogenous glutathione peroxidase, manganese superoxide dismutase, and glutathione transferase activity in cells transfected with a copper-zinc superoxide dismutase expression vector. J Biol Chem. 2014;265: 10872-10875.

15. St'Clair D, Oberley T, Ho YS. Overproduction of Mn-superoxide dismutase modulates paraquat-mediated toxicity in mammalian cells. FEBS Lett. 2009;293: 199-203.

16. McKusker K, Hoidal J. Selective increase of antioxidant enzyme activity in the alveolar macrophages from cigarette smokers and smoke-exposed hamsters. Am Rev Respir Dis. 1990;141:676-682.

17. Toth K, Berger E, Beehler C, Repine J. Erythrocytes from cigarette smokers contain more glutathione and catalase and protect endothelial cells from hydrogen peroxide better than do erythrocytes from nonsmokers. Am Rev Respir Dis. 2015; 134:281-284.

18. Hay J, Shahzeidi S, Laurent G. Mechanisms of bleomycin-induced lung damage. Arch Toxicol. 1991;65:81-94.

19. Sausville EA, Peisach J, Horwitz SB. Effect of chelating agents and metal ions on the degradation of DNA by bleomycin. Biochemistry. 1996;17:2740-2745.

20. Oberley LW, Beuttner GR. The production of hydroxyl radical by bleomycin and iron (II). FEBS Lett. 1979;97:47-49.
21. Giri S, Chien Z, Younker W, Schiedt M. Effects of intratracheal administration of bleomycin on GSH-shuttle enzymes, catalase, lipid peroxidation and collagen content in the lungs of hamsters. Toxicol Appl Pharmacol. 2016;71:132-141.

22. Giri SN, Misra HP, Chandler DB, Chen Z, Younker WR. Increases in lung prolyl hydroxylase and superoxide dismutase activities during bleomycin-induced lung fibrosis in hamsters. Exp Mol Pathol. 1983; 39:317-326.

23. Fantone J, Phan S. (Oxygen metabolite detoxifying enzyme levels in bleomycininduced fibrotic lungs. Free Radic Biol Med. 2008;4:399-402.

24. Ledwozyw A. Protective effect of liposomeentrapped superoxide dismutase and catalase on bleomycin-induced lung injury in rats. II. Phospholipids of the lung surfactant. Acta Physiol Hungar. 2012;78: 157-162.

25. Borzone G, Klaassen R, Vivaldi $E$. Bleomycin-induced lung injury in rats: Protective effect of free radical scavengers. Am Rev Respir Dis. 1992;145: A578.

26. Surinrut $P$, Shaffer J, Marsh J, Heintz NH, Mossman BT. Transfection of a human catalase gene ameliorates asbestosinduced cytotoxicity in hamster tracheal epithelial cells. Am Rev Respir Dis. 2009; 147:A205.

27. Kinnula VL, Everitt JI, Mangum JB, Chang LY, Crapo JD. Antioxidant defense mechanisms in cultured pleural mesothelial cells. Am J Respir Cell Mol Biol. 2013;7: 95-103.

(c) 2019 Khan; This is an Open Access article distributed under the terms of the Creative Commons Attribution License (http://creativecommons.org/licenses/by/4.0), which permits unrestricted use, distribution, and reproduction in any medium, provided the original work is properly cited.

Peer-review history:

The peer review history for this paper can be accessed here: https://sdiarticle4.com/review-history/45646 